\title{
Service Sector: Systematization of a Toolkit for Investment Activity Efficiency Evaluation
}

\author{
Yerokhina Lidiya Ivanovna \\ Korchagin Pavel Valentinovich
}

Volga Region State University of Service, 4 Gagarina street, Tolyatti, 445677, Samara Region

\section{Doi:10.5901/mjss.2015.v6n3s2p666}

\begin{abstract}
The article is dedicated to systematization of a toolkit for evaluation of investment efficiency in the service sector. Taking into account the domestic and international experience in investment projects evaluation accumulated in the recent years the author specified criteria of investment advisability in the service sector and offered a system of indices to assess investment activity efficiency in the service sector.
\end{abstract}

Keywords: service sector, investment, investor, recipient, investment project, investment efficiency.

\section{Introduction}

For an investor evaluation of the investment efficiency in the service sector is important in terms of acquisition of income and for a recipient in terms of profitability as well as possible bankruptcy and the threat of takeover by an investor (Vadel, 2011). The major part of methodologies for determining the efficiency of investments and investment projects developed by national experts and authorities of the Russian Federation is based on foreign methodologies, in particular the procedures of UNIDO, World Bank and EBRD. Direct use of the foreign methodologies in Russia involves difficulties for a number of reasons:

- the Russian system of taxation differs from the same in foreign countries;

- specificity of accounting;

- insufficient development of market relations, restrictions in information sphere.

This is precisely why "Guidelines for evaluation of investment projects efficiency and their selection for financing" (second edition) were initially published in 1994 and then in 2000. This document is consistent with approaches of UNIDO which are a kind of international standard for substantiation of investment efficiency and makes allowances for the Russian specific conditions at the same time.

The above guidelines declare use of the following main principles:

1. alternativity;

2. modeling of product and resources flows in a form of monetary funds;

3. projects appraisal in a number of aspects: technical, commercial, institutional, environmental, social, financial and economic;

4. use of internationally accepted criteria for assessing the investment projects efficiency;

5. assessment of uncertainty and risk (Daskovskiy \& Kiseliov, 2009).

The guidelines prepared by native specialists, for example Volkova I.M. and Gracheva M.V.; Bocharov V.V.; Sheremet A.D and Sayfulin R.S; Krylov E.I., Zhuravkova I.V. and Vlasova V.M., and other which appeared subsequently, are based on the above "Guidelines" when relate to determination of investment projects efficiency (Volkov \& Gracheva, 1998; Bocharov, 1993; Sheremet \& Sayfulin,1997; Krylov, Vlasova \& Zhuravkova, 2003; Endovitsky, 2001). This is largely due to the desire of Russian specialists to achieve a uniform approach in investment projects evaluation with consideration for domestic and foreign experience accumulated in recent years.

\section{Main Part}

Systematization of a toolkit for evaluation of investment activity efficiency in the service sector (see Table 1) performed by us has demonstrated that a combination of discounted and non-discounted methods of investment evaluation is widely used in the modern economic literature. 
Table 1. Systematization of a toolkit for evaluation of efficiency of investment activity in the service sector

\begin{tabular}{|c|c|c|c|}
\hline \multirow[t]{2}{*}{ Method } & \multicolumn{2}{|l|}{ Index } & \multirow[t]{2}{*}{ Criteria } \\
\hline & Description & Arithmetic formula & \\
\hline \multirow[t]{3}{*}{$\begin{array}{l}\text { Method based on } \\
\text { calculation of investment } \\
\text { repayment term }\end{array}$} & Repayment term & $\begin{array}{l}T=C / / \\
\text { where } T \text { - repayment term; } \\
C \text { - capital investment; } \\
I-\text { average annual income. } \\
T=C /\left(I_{n}+D\right) \text { or } \\
T=C / P n, \\
\text { where } / n \text { - net income; } \\
D-\text { depreciation expenses; } \\
P n \text { - net profit. }\end{array}$ & \multirow[t]{3}{*}{$\begin{array}{l}\text { The criterion of investment advisability is } \\
\text { determined by comparison of a repayment } \\
\text { term with an economically sound term as } \\
\text { established by a recipient or an investor. }\end{array}$} \\
\hline & Investment repayment term & $\begin{array}{l}T r=I / N P \\
\text { where I- investment; } \\
N P \text { - net profit. }\end{array}$ & \\
\hline & Period of return & $\begin{array}{l}T j=A j /(E j-B j), \\
\text { where } T j-\text { period of return; } \\
A j \text { - capital investment; } \\
E j \text { - earnings; } \\
B j \text { - operating expenses. }\end{array}$ & \\
\hline \multirow[t]{3}{*}{$\begin{array}{l}\text { Method based on } \\
\text { determining a rate of } \\
\text { profit for capital }\end{array}$} & Rate of profit for capital & $\begin{array}{l}\text { Rpc }=\frac{\sum I / T}{C} * 100 \\
\text { or } \\
\qquad \begin{array}{l}\text { Rpc }= \\
\text { where Cres }- \text { residual value of } \\
\text { investment. }\end{array}\end{array}$ & \multirow[t]{3}{*}{$\begin{array}{l}\text { The criterion of investment advisability is } \\
\text { determined by comparison of an } \\
\text { accounting rate of profit for capital with the } \\
\text { minimum or average rate of return with the } \\
\text { achieved rate and with the rate of return } \\
\text { characteristic for a definite class of } \\
\text { investment. }\end{array}$} \\
\hline & Simple rate of profit & $\begin{array}{l}\operatorname{Srp}=P n / I^{*} 100 \text { or } \operatorname{Srp} \\
=(P n+D E) / /{ }^{*} 100 \\
\text { where } D E-\text { depreciation } \\
\text { expenses. }\end{array}$ & \\
\hline & Investment profitability & Pinv $=P / /$ & \\
\hline \multirow[t]{2}{*}{$\begin{array}{l}\text { Method of comparative } \\
\text { efficiency of reduced } \\
\text { costs }\end{array}$} & Reduced costs & $\begin{array}{l}\mathrm{Zi}=\mathrm{Ci}+\mathrm{ErKi} \text {, } \\
\text { where } \mathrm{Zi} \text { - total costs acc. to } \\
\text { "i" variant } \\
\mathrm{Ci} \text { - current costs acc. to } \\
\text { "i" variant; } \\
\mathrm{Er} \text { - rate of profit for capital; } \\
\mathrm{Ki}-\text { capital investments acc. } \\
\text { to "i" variant. }\end{array}$ & \multirow[t]{2}{*}{$\begin{array}{l}\text { The criterion of investment advisability is } \\
\text { the least value of reduced costs. }\end{array}$} \\
\hline & $\begin{array}{l}\text { Coefficient of comparative } \\
\text { efficiency }\end{array}$ & $K e=(C 1-C 2) /(K 1-K 2)$ & \\
\hline $\begin{array}{l}\text { Method of comparison of } \\
\text { profit }\end{array}$ & Net profit & $\begin{array}{l}\sum_{\text {Pni= }}^{T_{i=1}} \text { Pnit }, \text { where Pni-net } \\
\text { profit value for the hole term of } \\
\text { investment; } \\
\text { Pnit - mass of net profit earned } \\
\text { for the 1st year of an investment } \\
\text { project realization; } \\
\text { Tul - useful life of an } \\
\text { investment project. }\end{array}$ & $\begin{array}{l}\text { The criterion of investment advisability is } \\
\text { the maximum value of profit from a project. }\end{array}$ \\
\hline $\begin{array}{l}\text { Method of accumulated } \\
\text { balance of money flow }\end{array}$ & $\begin{array}{l}\text { Balance of accumulated } \\
\text { effect }\end{array}$ & $\begin{array}{l}\quad \sum_{\text {Ea= }}^{T} \text { Eai }, \text { Eai=Ini-Acb, } \\
\text { where Ea - balance of } \\
\text { accumulated effect; } \\
\text { Eai - combined effect of } \\
\text { operating and investment } \\
\text { activities for the } 1^{\text {st } y e a r ~ o f ~ a ~} \\
\text { project use; }\end{array}$ & $\begin{array}{l}\text { When alternative investment projects are } \\
\text { compared the project with the maximum } \\
\text { balance of accumulated effect will be more } \\
\text { attractive. }\end{array}$ \\
\hline
\end{tabular}




\begin{tabular}{|c|c|c|c|}
\hline & & $\begin{array}{l}\text { Ini-net income from operating } \\
\text { activity for the } 1 \text { st year of a } \\
\text { project use inclusive of the } \\
\text { amount of net profit and } \\
\text { depreciation costs; } \\
\text { Acb-balance of inflows and } \\
\text { outflows per each year of } \\
\text { investment activity of an } \\
\text { enterprise. }\end{array}$ & \\
\hline $\begin{array}{l}\text { Method of net present } \\
\text { value }\end{array}$ & Net present value (NPV) & $\begin{array}{l}N P V=P V-I 0 \text { or } \\
\qquad \sum_{t=1}^{n} C F /(1+r)^{t}-I 0 \\
\text { where } P V-\text { present value of } \\
\text { money flows; } \\
\text { IO - initial investment costs; } \\
C F-\text { net money flow within } t \\
\text { period; } \\
R-\text { project discount rate; } \\
n-\text { planned project realization } \\
\text { term. }\end{array}$ & $\begin{array}{l}\text { When alternative investment projects are } \\
\text { compared the project with the maximum } \\
\text { NPV is preferred. }\end{array}$ \\
\hline $\begin{array}{l}\text { Method of internal rate of } \\
\text { return }\end{array}$ & Internal rate of return (IRR) & $I R R=N P V / I^{*} 100$ & $\begin{array}{l}\text { Advisability of investing in an investment } \\
\text { project is determined by comparing an } \\
\text { internal rate of return with a weighted } \\
\text { average cost of capital taken as the } \\
\text { minimum acceptable rate of return. }\end{array}$ \\
\hline $\begin{array}{l}\text { Method of profitability } \\
\text { index (earning power, } \\
\text { rate of return) }\end{array}$ & Profitability index (PI) & $\begin{array}{l}\text { In case of one-time investment: } \\
P l=P V / I . \\
\text { In case of multiple inpayments: } \\
\quad P V t / \sum_{t=1}^{n} I /(1+r)^{t} \\
P l=\end{array}$ & $\begin{array}{l}\text { If the profitability index is greater than one } \\
\text { then the project is considered economically } \\
\text { attractive. }\end{array}$ \\
\hline
\end{tabular}

The undiscounted or static evaluation methods are easy to use and effective under conditions of limited economic information. However, they have such significant disadvantages like ignoring a factor of time and future cash flows having relation to the investments being made (Berkovitch \& Narayanan, 1993).

On the other hand the discounted methods for assessing the effectiveness of investment eliminate these disadvantages and enable reduction of diverse costs and results to a consistent form with the year under analysis (evaluation) (Hirshman, 1961).

However it should be noted that the toolkit employed involves differences in terminology, methods of calculating indicators and abbreviations used.

Systematization of tools also allows to draw a conclusion that in most cases guidelines, individual indicators and methods for evaluating investments efficiency are used in a fragmentary manner. At the same time there can be observed a process of development of a domestic methodological framework for investment efficiency assessment and approximating it to the Western European and North American variant (Aoki, 1990). The existing techniques and methods are focused on evaluation of investment processes efficiency nevertheless the offered toolkit can be successfully used for assessment of effectiveness of investment activity of an enterprise, an individual industry or a region and for taking the appropriate managerial decisions.

A lot of Russian specialists offer quite a wide range of estimates for substantiation of optimal investment solutions. However we can agree with those who believe that in practice the choice of tools depends on the conditions specific for an investor and a recipient. Therefore the number of tools to assess the efficiency of investment can be somewhat reduced (Mylnik, 2002). In addition systematization of the investment efficiency assessment toolkit demonstrated that the following aspects could be regarded as criteria of investment advisability in the service sector:

- minimization of capital investment repayment time;

- low price of a project;

- stability of revenues from a project for a long period of time;

- $\quad$ high investment profitability;

- sufficiency of investment resources for implementation of a project;

- absence of more favorable alternatives; 
- reduction of the risk of losses due to inflation etc

The tools offered for assessing the effectiveness of investment projects at the level of an enterprise can be extrapolated to other objects (Pike \& Neale, 1993), in particular to the service sector. Considering the service sector as a qualitatively homogeneous group of business units we of course understand that it differs from an enterprise in respect of size, complexity, scale of investment, diversity of investment projects, generalized and averaged nature of information.

Thus a set of indices and methods of assessment of investment activity in the service sector is being determined by definite factors (Lewis, 1995). At the same time a basis of comparison of the resulting estimate indices is by no means unimportant as well. As is known at present there were developed clear criteria of estimation for a lot of indices. Nevertheless none of the unique estimate indices for investment activity does exist.

We maintain that with regard to the service sector a real interest rate for a credit adjusted to reflect deposit operations may be used as a basis for comparison of investment activity efficiency (Impavido, Musalem \& Tressel, 2001).

Judging from the above we can come to a conclusion that evaluation of the efficiency of investment activity of the service sector should be performed on the basis of combination of the static and dynamic indices. In this connection we offer to use the following indices:

- repayment term of investments in the service sector;

- profitability of investments in the service sector;

- $\quad$ net present value of the service sector;

- $\quad$ profitability index of the service sector;

- internal rate of return of the service sector;

- discounted repayment term of investments in the service s sector.

As we see it the problem does not consist in selection of a range of indices for assessment of investment activity efficiency in the service sector but in establishment of a basis of estimate for the said indices. Thus definition of a ratio of the volume of investment to the gross mass of profit is rather common approach for calculation of the repayment term (Krylov, Vlasova \& Zhuravkova, 2003). It seems that for the service sector this index would be too generalized and biased. In our opinion the most suitable method to determine the term of repayment for investments in the service sector would be comparison of a volume of investments with a balanced financial result of operation of organizations in the service sector which is a final "cleared" financial result of the service sector activity.

It is also offered to calculate the repayment term of investments by means of comparison of an investment volume with a sum of net profit and depreciation expenses. Use of such approach in regard of the service sector involves some difficulties since net profit and depreciation expenses as internal sources of investment financing often disperse inside the various current assets items and are not used for investment financing. Nevertheless we believe that in order to determine repayment term of investments in the service sector it is necessary to take into account both the balanced financial results and the depreciation expenses. Therefore we offer to use the following formula:

$$
T i=12 \times \frac{K i}{B F R+E d} \text {, }
$$

where $\mathrm{Ti}$ - repayment term for investments in the service sector (months);

$\mathrm{Ki}$ - capital costs in the service sector (mln rubles);

BFR - balanced financial result in the service sector (mln rubles);

Ed - depreciation expenses in the service sector (mln rubles).

Unfortunately this index does not take into account the time factor and future revenues; its use is influenced by the subjective approach of the management of an investor and a recipient to the definition of an economically viable repayment period (Bromwich, 2006; Bromwich, 1990). The repayment period gives an opportunity of prompt evaluation of investment situation in the service sector especially under the conditions of shortage of information and serves as a guide for the future investment decisions which by the way may appear to be wrong.

That's why even during the initial evaluation of investment activity efficiency in the service sector it is necessary to analyze the investment profitability in the service sector along with the investment repayment term. We offer to use the following formula to access the investment profitability in the service sector:

$$
R i=\frac{B F R / 12}{[K i+(K i-E d) / 2]} * 100 \text {, }
$$

where $\mathrm{Ri}$ - investment profitability in the service sector.

We'd like to give some explanation to the above formula. The denominator contains the average value between the initial and the residual investments with consideration of the fact that a part of the initial investment was used for refund of fixed assets depreciation in the service sector. 
For taking a final decision on short-term investment in the service sector an investor should analyze the repayment term of investments and their profitability in the aggregate with due account for investment differentiation by targets. Of course it is much easier to be done at the level of an individual enterprise and specific investment projects rather then of the service sector as a whole. That's why we consider taking decisions on medium-term and long-tern investment based only on statistical indices to be improper and risky.

We think that an investor will be able to get the most objective idea of the status of investment activity in the service sector judging from the analysis of dynamic indices the results of which could be successfully used for investment decisions with various time-related characteristics.

Such dynamic index as a net present value (NPV) is aimed at achievement of the main investment target, i.e obtaining of income in the form of profit agreeable for an investor. In the foreign and home practice this index represents a difference between discounted money income on an investment project within the planned term of its implementation and the initial value of investment expenditures.

We are of the opinion that advisability of investment in the service sector may be determined based on evaluation of the net present value of the service sector for a certain period of time prior to the time of taking the investment decision.

In case of one-time investment this index should be calculated as follows:

$$
N P V=\sum_{t=0}^{T} D t \times K D t-K i,
$$

where $\mathrm{Dt}$, - money income of the service sector per year t;

$\mathrm{KDt}$, - discounting coefficient per year t;

$\mathrm{Ki}$ - lumpsum investment costs in the service sector.

But as the investment process is often extended in time for the more objective evaluation of the efficiency of investment activity in the service sector it is desirable to determine NPV of the service sector for the whole period of investment (or the year of an investor's concern). And in this case we should make some clarification:

- first of all, for calculation of the discounting coefficient we use the weighted average interest rate for deposit and loan operations with account for all of the maturities on loans granted to enterprises and organizations;

- secondly, total mass of profit is taken as money income of the service sector;

- thirdly, for elimination of the effect of inflation money income of the service sector should be divided by the headline inflation index.

Then formula (3) will assume the following form:

$$
N P V=\sum_{t=1}^{T}(P t / I t) \times K D t-\sum_{t=1}^{T} K t D t \text {, }
$$

where $P_{t}$ - total mass of profit in the service sector within period $t$;

It - headline inflation index within period t;

$K t D t$ - capital expenditures reduced by the beginning of an investment period.

The profitability index according to some experts is considered to be more efficient estimate as compared to the net present value (Lucar, 1988). But in our opinion this index should be used jointly with other estimate indices thus performing its specific functions and not magnifying its advantages over other indices. Therefore to determine the overall picture of the effectiveness of investment activity in the service sector we offer to use it as well.

The service sector profitability index $(P l)$ is a ratio of the discounted money income and the value of initial investment (in case of one-time investment expenditures). If investments to the service sector were made during a number of years this index should be calculated as a ratio between the discounted money income of the service sector and the value of reduced investment expenditures based on the following formula:

$$
P I=\sum_{t=1}^{T} P t \times K D t / \sum_{t=1}^{T} K t D t,
$$

To justify the investment decisions relating to involvement of borrowed funds into the service sector such index as internal rate of return (IRR) of the service sector which corresponds to the interest rate (discount rate) at which the net present value of the service sector becomes equal to zero may be used. The following equation serves for calculation of the said index:

$$
\sum_{t=0}^{T} P t \times K D t-\sum_{t=0}^{T} K i t=0
$$

Solution of equation (6) gives an opportunity to determine the formula for defining the internal rate of return of the 
service sector:

$$
I R R=\sqrt[T]{\sum_{t=0}^{T} P t / \sum_{t=0}^{T} K i t}-1
$$

$P t$ - money income of the service sector within the corresponding year $t$;

Kit - capital investments of the service sector in year t.

The internal rate of return serves as a criterion of appropriateness of additional investments in the service sector. The said rate is the minimum value of profitability which ensures repayment of the borrowed money within the planned duration of a project, while always being compared with the price of capital. We consider a refinancing rate or a deposit rate to be the most appropriate comparative basis for the service sector. Application of the internal rate of return as an estimate index of the investment activity efficiency allows to calculate a potential rate of income on investment in the service sector a well as to determine the growth rate of the capital invested in the service sector.

The discounted repayment term of investments which makes provision for the time factor effect is more advanced as compared to the static index of the investment repayment term. The said index may be also used for evaluation of the service sector investment efficiency and for establishing the level of investment risk related to liquidity.

\section{Findings}

Use of the methods of evaluation of the service sector investment activity efficiency as developed by us will enable determining investment-perspective and investment-unfeasible kinds of services based on NPV index values.

\section{Conclusion}

Our research is based upon assumption that use of various indices (static or dynamic) for evaluation of the service sector investment activity efficiency is determined by a specific situation and those tasks which were set prior to evaluation. Given the limited information and the need for rapid decision-making use of the static estimates will be sufficient enough. In case of large-scale tasks with more or less long-term perspective use of dynamic evaluation methods will be more reasonable. We tend to think that these methods provide an investor with an objective picture of investment activity in the service sector, allow to perform a comparative analysis in order to identify the most attractive areas of capital investment and to make appropriate management decisions. Evaluation of investment activity efficiency which was based on the dynamic indices makes it possible to determine investment attractiveness of the service sector and serves as a guide for search of a potential investor.

\section{References}

Aoki, M. (1990). Toward an Economic Model of the Japanese Firm. Journal of Economic Literature, 38, 1-27.

Berkovitch, E., \& Narayanan, M.P. (1993). Timing of investment and financing decisions in imperfectly competitive financial markets. Journal of Business, 66, 2, 219-248.

Bocharov, V. V. (1993). Financial and credit methods for investment market regulation. Moscow: Finansy i Statistika (In Russian).

Bromwich, M. (2006). Analysis of investment efficiency. Moscow: INFRA-M (In Russian)

Bromwich, M. (1991). Al Bhimani Strategic Investment Appraisal. Management Accounting, 3, 45-48.

Daskovskiy, V.,\& Kiseliov, V. (2009). Improvement of investment performance evaluation. Economist, 1, $42-57$ (In Russian).

Endovitsky, D.A. (2001). Integral analysis and control of investment activity: methodology and practice. Moscow: Finansy i Statistika (In Russian).

Hirshman, A. (1961). The Strategy of Economic Development. 2 nd ed. New Heaven

Impavido, G., Musalem, A.R., \& Tressel , T. (2001). Contractual Savings Institutions and Bank's Stability and Efficiency.

Krylov, E.I., Vlasova, V.M., \& Zhuravkova I.V. (2003). Analysis of efficiency of investment and innovative activity of an enterprise.

Lewis, W. (1959). The Theory of Economic Growth.

Lucar, R. (1988). On the Mechanism Economic Development. Journal of Monetary Economic, 22, 3-42

Mylnik, V.V. (2002). Investment management: Study guide. Moscow: Akademicheskiy proekt (In Russian).

Pike, R., \& Neale, B. (1993). Corporate Finance and Investmen (Decisions and Strategies). London: Prentice Hall.

Sheremet, A. D., \& Sayfulin, R. S. (1997). Business finance. Moscow: INFRA-M (In Russian).

Vadel, O.A. (2011). Management of an investment project efficiency within the concept of a value-related approach. Management in Russia and Abroad, 6, 35-42 (In Russian).

Volkov, I. M., \& Gracheva, M. V. (1998). Project analysis. Textbook for higher educational institutions. Moscow: Banki i Birzhi; UNITY (In Russian). 